\title{
Assessment of Teachers' Personality Traits As A Predictor Of Students' Academic Performance In Chemistry In Senior Secondary Schools In Osun State
}

\author{
S. Olayinka Olajide. (Ph.D) \\ Institute of Education, \\ Obafemi Awolowo University, Ile-Ife, Nigeria. \\ Adebayo, A. Aderonke \\ Department of Science and Technology Education, \\ Obafemi Awolowo University, Ile-Ife, Nigeria.
}

\begin{abstract}
The study assessed teachers' personality traits as a predictor of students' academic performance in Chemistry in senior secondary schools in Osun State. It investigated and analysed relationship between teachers' personality traits such as attitude, qualification, and knowledge of subject matter etc. on students' academic performance in Chemistry in senior secondary schools in Osun State. These were with a view to providing information on students' academic performance in the subject in the study area. The study adopted the descriptive survey research design. The population for the study comprised all Chemistry students and their teachers in senior secondary schools in Osun State. Three hundred senior secondary two (SSII) students were randomly selected from thirty randomly selected senior secondary schools in Osun State using simple random sampling technique. All the Chemistry teachers in the all the selected schools were purposively used for the study. The three instruments used for data collection are; Teachers' Personality Traits Questionnaire (TPQ), Students' Perception of Teachers' Personality Traits Questionnaire (SPTPTQ) and Students' Results in Chemistry in their previous terms. The results of the study showed that there is significant relationship between teachers' attitude and students' academic performance in Chemistry $(r=0.087 ; p<0.05)$. The results of the study also revealed that there is significant relationship between teachers' qualification and students' academic performance in Chemistry $(F=0.025 ; p<0.05)$. The results of the study further showed that there is significant relationship between teachers' knowledge of subject matter and students' academic performance in Chemistry $(r=0.210 ; p<0.05)$. Moreover, the results of the study revealed that there is significant relationship between teachers' self-efficacy and students' academic performance in Chemistry $(r=0.125 ; p<0.05)$, and finally the results of the study showed that there is significant relationship between teachers' years of experience and students' academic performance in Chemistry $(F=0.100 ; p<0.05)$. The study concluded that teachers' personality traits predict students' academic performance in Chemistry in senior secondary schools.
\end{abstract}

Keywords: Teacher, Personality Traits, Predictor, Performance.

\section{INTRODUCTION}

Education is widely regarded as a basic human right, a key to enlightenment, and a source of wealth and power (Mugenda \& Mugenda, 1999). Education is critical to industrial and technological development, with the history of developed nations bearing records of this, developing nations aspiring to realize the same status have to put a premium. United Nations Educational, Scientific and Cultural Organization UNESCO (1986) indicates that knowledge 
holds key to the attainment of millennium development goals, which include, food security, eradication of child mortality, and reduction of the spread of HIV and AIDS among others.

Education is a cooperative teaching-learning process of preparing an individual from birth and all through his/her life for happy useful living in the society within the culture and the resources (Adesoji \& Olatunbosun, 2008). It then follows that education is a social service which ensures refinement of human behaviour in terms of his/her processes of reasoning, feeling and doing things in a happy expectancy.

Throughout the world, education is considered to be the very important tool for attaining national goals. Education provides learners with skills needed for survival. In view of the federal Government of Nigeria introduction of the Universal Basic Education whereby education is free and compulsory for all citizenry at least to the secondary level of education, it is important to utilize the value of science. Science and chemistry education in particular is a veritable instrument for national development. According to Okon - Enoh, (2008) science is a way of seeking information (process) and also an accumulated knowledge resulting from research (products). Okoro (2013) sees science as a systematic investigation of nature with a view to understudy and harnessing them to serve human needs. Science may be regarded as the body of related courses concerned with knowledge. It consists among other component; Chemistry, Physics, Biology, Mathematics, Astronomy, Agriculture, among these, Chemistry is vigorously described as the queen of science. Realizing the role science plays in achieving selfreliance and intellectual development, one tries to find the place of chemistry in science. Notwithstanding the negative role chemistry education does play globally, such as pollution and drug abuse, the positive roles are well known. Chemistry is the central in the drive of global sustainable economic development. It plays the major roles in food (fertilizers and insecticides), clothing (textile fibres), housing (cement, concrete, steel, bricks), Medicine (drugs), Transportation (fuel, alloy materials). Presently, man is experiencing an era in scientific and technological development that affects his life in one way or the other. Virtually everything we use daily involves science.

There are hues and cries among stakeholders in education over the growing rate of failure and subsequent drop-out in the Nigeria secondary schools in recent time. The growing failure rate could be noticed in the yearly decline in the West African Senior School Certificate Examination (WASSCE). There have been reported incidences of underachievement in secondary school students evidenced by poor performances in WAEC results over the years. According to statistics in Daily Champion of $4^{\text {th }}$ April 2010 analysing the results of the 2010 May/June WASSCE, only 337,071 candidates representing 24.94 per cent, out of 1,351,557 candidates who wrote the examination obtained five effective credits and above. Effective credits simply mean that the subjects' combinations include English Language and Mathematics which are compulsory for admission into the Universities in Nigeria. The result shows a marginal one per cent lower than lasts' year result. But 77,168 others based on reports of examination malpractice will not have their results. It should be recalled that in the May/June 2009 examination only 356,981 candidates representing 26 per cent of the 1,373,009 students who sat for examination obtained five effective credits. Also, in the November/December examination meant for private candidates last year recorded a similar poor performance. The worst result so far was recorded in the May/June examination of 2012. Out of a total of 1,369,142 candidates that sat for the examination, only a meagre 188,442 representing 13.76 per cent obtained five effective credits and above. The truth is that once a candidate fails to obtain the required five effective credits in the first attempt, he/she is bound to retake the examination to make up the deficient subjects. Failure to make up those subjects effectively shuts the candidate out of university admission. Private schools are not necessarily better. This 
poor performance had its effect in Chemistry performance, according to Chief Examiner's report analysing the results of Chemistry in 2007 May/June WASSCE, out of 434,460 candidates who wrote Chemistry, only 196,081 candidates representing $46.16 \%$ obtained Credits and above while 105,602 candidates representing $24.86 \%$ had a Pass and 112,637 representing $26.51 \%$ failed the examination. The result became worse in May/June 2008 WASSCE, when 468,291 candidates registered for Chemistry and only 198,621 candidates representing $43.46 \%$ passed the examination.

This situation has unpleasant implications for the youths and future of the country. These results have shown a steady drop in students' academic achievement in Chemistry and this trend has continued despite efforts by psychologists, educationists and all concerned to effect change. Stakeholders in education blamed students for general unpreparedness to study as one of the major causes for students' failure. Teachers were also blamed for lack of dedication to their jobs which has inadvertently affected the academic performance of students. Also, some teachers adopted the use of corporal punishment to curb indiscipline among student which in turns create fear in student towards their teacher and thus decline teacher-student relationship. Whoever to be blamed, the general view is that teachers' with relevant personality traits are education's best resources and assets (Ayodele 2004).

While education is a cooperative teaching/ learning for effective citizenship and collective benefit of society, secondary school is a link between primary and tertiary institution where adequate knowledge for effective citizenship and collective benefits of the society is achieved. A teacher is thus the bridge that makes teaching and learning effective, he is thus the builder whose performance depends on adequate qualification, experience and preparation. This adequate knowledge and experience could be attained or achieved by acquiring additional knowledge that will stimulate his/her communication in teaching for efficiency. It is therefore evident that the heart of Nigeria educational system is the teacher and that teachers are the major indicator and determinant of quality education. Obayan (2004) noted that teachers are considered instrumental to translating content standards into teachable classroom lessons; the teacher remains a constant factor in the successful implementation of any educational program.

Teachers have been universally accepted as one of the most important component of education (Sikora, 1997). The competent teacher is sure to affect the educational outcomes of his or her students in many positive ways. Umoren and Ogbodo (2001) pointed out that emotional stability is one of the needed competences of the teacher. They emphasized that teachers should be emotionally stable in order to change the students under their control. This leads to the question of the personality traits of the teachers.

Personality is the projection of teachers to others. It helps teachers to become sensitive to children's needs and give them the knowledge and skills required to create caring and wholesome learning environment. Personality according to Farrant (2004), is the product of a great many characteristics or traits. It encompasses the stability of the psychological make-up of the individuals. It is the sum total of the general characteristics which distinguishes an individual from every other person. Since it has to do with a collection of different aspects of a person's behaviour (profile), it is said to include the traits of ability, beliefs, attitudes, values, motivations, motives and habitual mode of adjustment (Anwana, 2004).

On teachers' personality, Adu \& Olatundun (2007) contend that teachers' characteristics are strong determinants of students' performance in secondary schools. Scholars and researchers generally are in agreement that the school variables, which include teacher's administration, 
perform a critical role in educational achievement than other variables (Patrick, 2005). The important role of the teachers in the learning is unquestionable. Teachers have a lot of influence on their classroom practices. Liard (2002) captures the basic premise of the facilitation theory developed by Carl Rogers by stressing that learning will occur by the educator when he establishes an atmosphere in which learners feel comfortable to consider new ideas and are not threatened by external factors. Teachers should have and apply specific abilities without which their influence may not be reflected in their students' performance in the subject they are teaching in schools. For students to be able to make connection between what is taught in school and its application in problem solving in real life, the teacher has to be effective in his/her teaching.

Adeogun (2003) opined that the quality of the educational system depends on the quality of teaching staff and that a school without human resources may not be able to achieve its goals and objectives of the educational system, highly professional teachers, who are dedicated, are needed in schools. It has been observed that non-professional teachers have greatly affected the academic performance of students' in senior secondary schools due to the inability to disseminate useful knowledge to students because of their non-professionalism. It has been established that there is high correlation between what teachers know and what they teach. Thus, the ability to disseminate effectively depends on the teachers' knowledge and knowledge occurs in a variety of forms. Teacher effectiveness is impeded if the teacher is unfamiliar with the body of knowledge taught and the teachers' effectiveness is subject-specific. The implication of this for teachers is that they must understand what they must teach the student thoroughly. A teacher who is a master of his/her subject matter uses clearer language, give specific examples when necessary and provides better explanation than those whose background is weaker.

It is also important that high level of learning occurs and learners feel good about themselves and materials they are learning when teachers use instructional time effectively. Ehindero and Ajibade (2000) asserted that 'students who are curious stakeholders in educational enterprise, have long suspected and speculated that some of their teachers lack the necessary professional qualifications, that is, skills, techniques, strategies required to communicate concepts, ideas, principles in a way that would facilitate effective learning. They believe that these deficiencies contribute significantly to the growing rate of failure of students in school subjects, most especially in sciences in secondary schools. These observations by stakeholders necessitate the need to investigate the effects of teachers' characteristics such as professional qualification, teaching skill and techniques necessary for teaching and learning on students' academic performance in Chemistry in secondary schools.

\section{STATEMENT OF THE PROBLEM}

The importance of Chemistry in most field of human endeavour cannot be underestimated, since Chemistry is needed in everyday life. Chemistry is a key subject that is taught right from Senior Secondary School level of education to tertiary level. Despite its importance and relevance in human life, studies have shown that students' performance in the subject at senior secondary school level of education is dwindled year in and year out. Various factors such as teaching methodologies, inadequate use of instructional materials, student interest, and the likes have been identified to be the major causes of this poor performance. However, teachers' personality traits (teachers' attitudes, teachers' self-efficacy, teachers' qualification etc.) have been identified to play a major role in students' academic performance in any school subjects most especially in Chemistry, but this has not been adequately focused and reported in Literature. This study therefore seeks to assess teachers' personality traits as a predictor of students' academic performance in chemistry in senior secondary schools in Osun State. 


\section{PURPOSE OF THE STUDY}

The purpose of the study is to assess the extent to which teachers' personality traits (teachers' attitude, teachers' self-efficacy, qualification, teachers' years of experience, teachers' knowledge of subject matter) relate to the students' academic performance in chemistry in senior secondary schools in Osun State. Hence, the specific objectives of the study are to;

1. assess the relationship between teachers' attitude and students' academic performance in chemistry in senior secondary schools in Osun State;

2. investigate the relationship between teachers' qualification and students' academic performance in chemistry in senior secondary schools in Osun State;

3. determine the relationship between teachers' knowledge of subject matter and students' academic performance in chemistry in senior secondary schools in Osun State;

4. analyse the relationship between teachers' self-efficacy and students' academic performance in chemistry in Osun State; and

5. investigate the relationship between teachers' year of experience and students' academic performance in Chemistry in the study area.

\section{HYPOTHESES}

1. There is no significant relationship between teachers' attitude and students' academic performance in chemistry.

2. There is no significant relationship between teachers' qualification and students' academic performance in chemistry.

3. There is no significant relationship between teachers' knowledge of subject matter and students' academic performance in chemistry.

4. There is no significant relationship between teachers' self-efficacy and students' academic performance in chemistry.

5. There is no significant relationship between teachers' year of experience and students' academic performance in chemistry

\section{Research Design}

\section{METHODOLOGY}

The descriptive survey research design was used for the study. The descriptive research design is a systematic method which involves collection of data from a large population for the purpose of analysing the relationships between variables. The design was chosen because the researchers collected information from a sample that is meant to represent a larger population. The researchers were interested in knowing whether there would be relationships between dependent variable and independent variables without necessarily manipulating the independent variables. Here, the dependent variable, which is (students' academic performance) is been paired with the independent variables (teachers' personality traits) to know both their joint and relative predictive values.

\section{Population for the study}

The population of the study comprised all chemistry students and their teachers in senior secondary school II (SSII) in Osun State.

\section{Sample and Sampling Technique}

The sample consisted of 300 Senior Secondary II (SSII) students offering Chemistry who were randomly selected from thirty senior secondary schools using simple random sampling technique. Ten students were randomly selected from each selected school. All the Chemistry teachers in all the selected schools were purposively used for the study because of their numbers in schools. 


\section{Research Instruments}

Three instruments were used for data collection. The three instruments were developed by the researchers and they are;

1. Teachers' Personality Traits Questionnaire (TPQ)

2. Students Perception of Teachers' Personality Traits Questionnaire (SPTPTQ) and

3. Students' Results in Chemistry for their Previous Terms.

\section{Teachers' Personality Traits Questionnaire (TPQ)}

This consists of two sections. Section A contains demographic information of the respondents and section B consisted of eight items on teachers' characteristics as a predictor of students' academic performance in Chemistry.

\section{Students Perception of Teachers' Personality Traits Questionnaire (SPTPTQ)}

This also consists of two sections. Section A sought for bio-data of the respondents and section $B$ consisted of twenty-five statements patterned after Likert from which respondents were to indicate their level of agreement on a Likert's rating scale from Strongly Agree (SA), Agree (A), Strongly Disagree (SD) and Disagree (D).

\section{Students' Results in Chemistry for their Previous Terms.}

These were collected from the school authority through the chemistry teachers in all the school used for the study. The results were students' result for first and second terms.

\section{Validity of the Instruments}

The first two instruments were given to experts in field of science for their comments on the structure and grammar of the instruments. Their corrections were used to prepare the final drafts that were used for the study.

\section{Procedure for Data Collection}

The researchers visited all schools used for the study, sought permission from the school authorities to use their schools for the study. The researchers thereafter met with the Chemistry teachers in all the schools, explained the purpose of their visit and sought for their permission and cooperation to use them and their students for the study. The questionnaire meant for teachers were given to them and after their completion, they were retrieved back immediately from the teachers. Furthermore, with the assistance of the Chemistry teachers in all the schools, the selected sample students were also given their own questionnaire to fill, after the completion they were retrieved back on the spot from the students.

\section{Data Analysis}

Data collected were analysed using mean, standard deviation and correlation coefficients. All these were achieved through the use of Statistical Packages for Social Science (SPSS).

\section{Testing of Hypotheses}

\section{RESULTS}

Hypothesis 1: There is no significant relationship between teachers' attitude and students' academic performance in Chemistry in senior secondary schools.

In order to test this hypothesis, data collected on teachers' attitude and students' academic performances in Chemistry in senior secondary schools were subjected to Pearson moment correlation and the result is presented in Table 1. 
Table 1: Pearson moment correlation of the relationship between teachers' attitude and students' academic performance in Chemistry in senior secondary schools.

\begin{tabular}{llllll}
\hline Groups & $\mathbf{N}$ & Mean & SD & r & Sig. (2-tailed) \\
\hline Teachers' attitude & 300 & 13.88 & 1.33 & 0.087 & .000 \\
Academic performance & 300 & 53.43 & 19.07 & & \\
\hline
\end{tabular}

$(\mathrm{r}=0.087, \mathrm{p}<0.05)$

Result in Table 1 showed that there is significant relationship between teachers' attitude and students' academic performance in Chemistry in senior secondary schools at $(\mathrm{r}=0.087, \mathrm{p}<0.05)$. Hence, the null hypothesis that states that there is no significant relationship between teachers' attitude and students' academic performance in Chemistry in senior secondary schools is hereby rejected. The result implied that teachers' attitude towards the subject contributed to the academic performance of the students in Chemistry.

Hypothesis 2: There is no significant relationship between teachers' qualification and students' academic performance in Chemistry in senior secondary schools.

In order to test this hypothesis, data collected on teachers' qualification and students' academic performance in Chemistry in senior secondary schools was subjected to regression analysis and the result is presented in Table 2.

Table 2: Regression analysis of the relationship between teachers' qualification and students' academic performance in Chemistry in senior secondary schools.

\begin{tabular}{lclccc}
\hline Model & Sum of Square & df & Mean Square & F & Sig. (2-tailed) \\
\hline Regression & .058 & 1 & .058 & .025 & .001 \\
Residual & 44.942 & 298 & .459 & & \\
Total & 45.000 & 299 & & & \\
\hline
\end{tabular}

$(\mathrm{F}=0.025, \mathrm{p}<0.05)$

Result in Table 2 showed that there is significant relationship between teachers' qualification and students' academic performance in Chemistry in senior secondary schools at $(\mathrm{F}=0.025$, $\mathrm{p}<0.05$ ). Therefore, the null hypothesis that states that there is no significant relationship between teachers' qualification and students' academic performance in Chemistry in senior secondary schools is hereby rejected.

Hypothesis 3: There is no significant relationship between teachers' knowledge of subject matter and students' academic performance in Chemistry in senior secondary schools.

In order to test this hypothesis, data collected on teachers' knowledge of subject matter and students' academic performance in Chemistry in senior secondary schools were subjected to pearson moment correlation and the result is presented in Table 3.

Table 3: Pearson moment correlation of the relationship between teachers' knowledge of subject matter and students' academic performance in Chemistry in senior secondary schools.

\begin{tabular}{llllll}
\hline Groups & N & Mean & SD & r & Sig. (2-tailed) \\
\hline Teachers' knowledge & 300 & 29.28 & 3.51 & 0.210 & .000 \\
Academic performance & 300 & 53.43 & 19.07 & & \\
\hline
\end{tabular}

$(\mathrm{r}=0.210, \mathrm{p}<0.05)$

Result in Table 3 showed that there is significant relationship between teachers' knowledge of subject matter and students' academic performance in Chemistry in senior secondary schools 
at $(\mathrm{r}=0.210, \mathrm{p}<0.05)$. Thus, the null hypothesis that states that there is no significant relationship between teachers' knowledge of subject matter and students' academic performance in Chemistry in senior secondary schools is hereby rejected. The result indicated that teachers' knowledge of subject matter dictates students' academic performance in Chemistry in senior secondary schools within the study area.

Hypothesis 4: There is no significant relationship between teachers' self-efficacy and students' academic performance in Chemistry in senior secondary schools.

In order to test this hypothesis, data collected on teachers' self-efficacy and students' academic performance in Chemistry in senior secondary schools were subjected to pearson moment correlation and the result is presented in Table 4.

Table 4: Pearson moment correlation of the relationship between teachers' self-efficacy and students' academic performance in Chemistry in senior secondary schools.

\begin{tabular}{lllllc}
\hline Groups & N & Mean & SD & r & Sig.(2-tailed) \\
\hline Teachers' self-efficacy & 300 & 41.11 & 3.47 & 0.125 & .000 \\
Academic performance & 300 & 53.43 & 19.07 & & \\
\hline
\end{tabular}

$(\mathrm{r}=0.125, \mathrm{p}<0.05)$

Result in Table 4 showed that there is significant relationship between teachers' self-efficacy and students' academic performance in Chemistry in senior secondary schools at $(\mathrm{r}=0.125$, $\mathrm{p}<0.05)$. Hence, the null hypothesis that states that there is no significant relationship between teachers' self-efficacy and students' academic performance in Chemistry in senior secondary schools is hereby rejected. The result pointed out that teachers' self-efficacy is a predictor of students' academic performance in Chemistry in senior secondary schools within the study area.

Table 5: Regression analysis of the relationship between teachers' years of experience and students' academic performance in Chemistry in senior secondary schools.

\begin{tabular}{lclccc}
\hline Model & Sum of Square & df & Mean Square & F & Sig.(2-tailed) \\
\hline Regression & 93.006 & 1 & 93.006 & .100 & .001 \\
Residual & 16317.744 & 298 & 166.508 & & \\
Total & 16410.750 & 299 & & & \\
\hline
\end{tabular}

$(\mathrm{F}=0.100, \mathrm{p}<0.05)$

Data presented in Table 5 showed that there is significant relationship between teachers' years of experience and students' academic performance in Chemistry in senior secondary schools at $(\mathrm{F}=0.100, \mathrm{p}<0.05)$. Hence, the null hypothesis that states that there is no significant relationship between teachers' years of experience and students' academic performance in Chemistry in senior secondary schools is hereby rejected.

\section{DISCUSSIONS OF FINDINGS}

The study had found out that there is a significant relationship between teachers' attitude and students' academic performance in Chemistry in Senior Secondary Schools. The result is in line with the findings of Adu and Olatunbosun (2007) when they found out that teachers' positive attitude affect students' academic performance. Also this corroborates with the findings of Adesoji and Olatunbosun (2008) which revealed that teachers' attitude to Chemistry teachings had a positive significant relationship to students' academic performance in Chemistry. 
Furthermore, the result of the study revealed that there is significant relationship between teachers' qualification and students' academic performance in Chemistry in senior secondary schools. This is in line with the findings of Emmanuel (2013); Ayodele (2004); Clotfelter, Ladd and Vigdor (2007) when they discovered that there is significant relationship between teachers' qualification and students' academic performance in Chemistry.

Also, the results obtained from the analysis carried out on data collected from the study found a positive relationship between teachers' knowledge of subject matter and students' academic performance. This is in support with the findings of Darling-Hammond L. (2000); Ehindero and Ajibade (2001), where they found out that there is a significant relationship between students' perception of teachers' knowledge of subject matter and students' academic performance. Hence, if a teacher knows his or her subject matter very well, it is obvious for students to like such a teacher and performed well in his/her subject.

Moreover, findings from the study also showed a positive relationship between teachers' selfefficacy and students' academic performance in Chemistry. This is in support with the work of Gibbons Kimmel O’Shea (1997).

Lastly, the results of the study revealed that there is significant relationship between teachers' year of experience and students' academic performance in Chemistry. The findings corroborate with the findings of Adu, (2007); Ayodele (2004); where they found that there is a positive significant relationship between teachers' years' of experience and students' academic performance in Chemistry.

\section{CONCLUSION}

The study had found out that teachers' personality traits predict students' academic performance in Chemistry. In order to foster students' academic achievement in Chemistry, priority should be given to the employment of professional and qualify teachers so as to enable them acquire experience on the job. The study had showed that perennial failures recorded in Chemistry at Senior School Certificate Examinations (SSCE) can greatly be attributed to teachers' personality traits.

\section{RECOMMENDATIONS}

Based on the findings of the study, the following recommendations are made:

1) There is need for Government to motivate teachers to boost productivity by providing them with necessary incentives such as adequate salaries, excellent work environment and other fringe benefits that compare favourably with what their counterparts in other profession receives.

2) The non-professional teachers should be encouraged to acquire relevant degrees in education to make them eligible for registration with the Teachers Registration Council of Nigeria (TRCN).

3) Government should also organize Seminars, conferences and workshops frequently to sensitize teachers on the need to always display acceptable behaviour while interacting with their students, in and outside the classroom and they also be encouraged to have a positive change of attitude towards the teaching of Chemistry so that performance of students' in external examinations will not be hindered.

4) The ministry of education should intensify efforts in the supervision of teachers in schools as a way of ensuring that the teachers exhibit unique qualities that can facilitate students' learning. 
Olajide, S. O., \& Adebayo, A. A. (2018). Assessment of Teachers' Personality Traits As A Predictor Of Students' Academic Performance In Chemistry In Senior Secondary Schools In Osun State. Advances in Social Sciences Research Journal, 5(12) 589-600.

\section{References}

Adesoji, F.A. \& Olatunbosun, S.M. (2008) Student, Teacher and School Environment Factors As Determinants of Achievement in Senior Secondary School Chemistry in Oyo State, Nigeria. The Journal of International Social Research Volume 1/2 page 13-34.

Adeyegbe, S.O.(2002). How students, examiners perform at WAEC examinations. Vanguard,Thursday, $19^{\text {th }}$ December, pp 22.

Adeyemi, T.O. (2007). Research methods and theses writing in educational studies. Lagos: New Heaven Publishers.

Adeyemo, D. A. (2005) "Parental Involvement Interest in Schooling and School Environment as predictors of Academic Self-efficacy among Fresh Secondary School Student in Oyo State, Nigeria." Electronic Journal of Research in Educational Psychology, 5 - 3:163 180.

Adu, E. 0 \& Olatundun, S. O. (2007) “Teachers' Perception of Teaching as Correlates of Students' Academic Performance in Oyo State Nigeria" Essays in Education, 20: 57-63.

Akinsolu, A.O. (2010) Teachers and Students' Academic Performance in Nigerian Secondary Schools: Implications for Planning Florida Journal of Educational Administration \& Policy Volume 3, Issue 2 pp86-103.

Ali, A.A (2009). The impact of teacher wages on the performance of students: Evidence from PISAmpra.ub.unimuenchen.de/.../impact of teacher wages on the...

Anwana, U.I (2004). Psychology: Aspects of human development (2nd Edition). Enugu: Academic Publishing Company.

Ashton, P. (1996). "Improving the Preparation of Teachers" Educational Researcher, 25 No. 9: 21-22.

Ayodele J.B (2004). "The Roles of the Head Teachers in School Plant Management and Maintenance" in Fagbamiye E.O, Babalola, J.B; Fabunmi, M; and Ayeni A.O. Management of Primary and Secondary Education in Nigeria. Ibadan NAEAP 93-100.

Bangbade, J.0; (2004). Effects of subject knowledge on the teaching and learning of biology and physics.

Carpenter, T, \& Lubinski, C. (1990). Teachers' attributions and belief about girls, boys \& Mathematics 21, 55-69.

Clotfelter, C. T., Ladd, H. F., \& Vigdor, J. L. (2007) Teacher Credentials and Student Achievement in High School: A Cross-subject Analysis with Student Fixed Effects. Working Paper 11 Washington, DC: Urban Institute, National Center for Analysis of Longitudinal Data in Education Research.

Darling-Hammond, L., Berry, B., \& Thorenson, A. (2001) Does teacher certification matter? Evaluating the evidence. Educational Evaluation and Policy Analysis, 23(1) 57-77.

Darling-Hammond, L., Chung, R., \& Frelow, F. (2002) Variation in teacher preparation: How well do different pathways prepare teachers to teach? Journal of Teacher Education, 53(4), 286-302.

Darling-Hammond L. (2000). Teachers' quality \& students' achievement. A review of state policy evidence. Educational Policy Analysis Achieves, 8(1). Retrieved on April 42011 from http://credo.stanford.edu/download/tfa.pdf.

Eggen, P \& Kaucher, D. (2001). Educational Psychology: Windows on Classrooms. New Jersey Prentice Hall Inc. Ehindero, O.J. \& Ajibade, Y.A (2000). What our student say about how we teach. Ife Journal of Educational Studies $7(1), 1-9$.

Emmanuel .B. (2013). The place of Nigeria certificate in Education chemistry Teachers in UBE Basic Science programme. STAN 54th Annual conference proceedings. 177-181.

Farrant, J.S (2004). Principles and practice of education (New edition). England: Pearson education limited.

Ferguson, R. F. (1991). Paying for Public Education: New Evidence on how and why Money Matters Harvard Journal of Legislation, 28:465-498.

Fisher, Berliner,D. Filby,N; Marliave,R;Cohen K; E. Dishaw, M, (1980). Teaching Behaviours Academic Learning time and Student Academic an Overview.

Fullan, M. G. (1992). Successful School Improvement: The Implementation Perspective and Beyond. Buckingham. Open University press, 1992.

Gibbons S, Kimmel, H \& O'Shea, M. (1997) Changing Teacher Behaviour through Staff Development: Implementing the Teaching and Content Standards in Science School Science and Mathematics; 976 (1):302-340. 
Goldhaber, D. D. \& Brewer, D. J. (2000) “Does Teacher Certification Matter? High school Teacher Certification Status and Student Achievement" Educational Evaluation and Policy Analysis, 22 (2):129-145.

Gravestock, P. \& Gregor-Greenleaf, E. (2008) Student Course Evaluations: Research, Models and Trends. Toronto: Higher Education Quality Council of Ontario.

Hardy \& Smith (2006). Relationship between teachrrs' qualification and students' academic achievement. Journal of Research in Education.

Hardy, I. \& Smith, E. (2006) 'Contesting Tertiary Teaching Qualification: An Australian Perspective' Teaching in Higher Education, Vol 11(2):337-350.

Hornby A.S (2010). Oxford Advanced Learners Dictionary of current English. Oxford: University press.

Huang, F.L. \& Moon, T.R. (2009) Is experience the best teacher? A multilevel analysis of teacher characteristics and student achievement in low performing schools Educ Asse Eval Acc 21:209-234.

Hung \& Moon (2009). Teachers' qualification as a predictor of students' achievement in Education. Jounal of Research in Education.

Liard, D. (2002). Approaches to training and development. Reading Mattles, 3, 311-332.

Maundu, J. N. (1986). Student Achievement in Science and Mathematics: A Case of Extra Provincial, Provincial, and Harambee Secondary Schools in Kenya. PhD Thesis. McGill University, Montrea.

Monk, D. H. (1994) "Subject Area Preparation of Secondary Mathematics and Science: Teachers and Student Achievement." Economic of Education Review, 13(1):125-145.

Murnane, R. J. (1996). The Impact of School Resources on the Learning of Inner-city children. Cambridge, MA: Ballinger.

Murnane, R.J. and Phillips, B.R. "What Do Effective Teachers Of Inner-City Children Have In Common?" Social Science Research 10, no. 1 (1981): 83-100.

Nbina, \& Barineka. J. ,(2012). Analysis of poor performance of Senior Secondary Students in Chemistry in Nigeria. An International Multidisciplinary Journal, Ethopia. pp 324-334.

Obanyan, P. (2004). The African Teacher of the 21 st Century. Ibadan Heinemann Educational Books.

Oderinde, B.B. ,2003. Examinations and Students' Performance. Thursday, January 16, Vangyard, 19(5167): 30.

Okoh-Enoh, E.E (2008). Realising the Goals of National Economic Empowerment and development strategy (NEEDS) and millennium Development goals (MDGs) Implication for science Education. Journal of Science Education, 8(1) 1-12.

Okoro, S.U.C. (2013). Attaining the MDGs through Effective STAN Education Delivery. STAN 54th Annual conference proceedings. 108-118.

Olaleye, F.O. (2011) Teachers Characteristics As Predictor Of Academic Performance Of Students In Secondary Schools In Osun State -Nigeria European Journal of Educational Studies 3(3),pp 505-511.

Owoeye, J. S. \& Yara, P. O. (2011) School Location and Academic Achievement of Secondary School in Ekiti State, Nigeria Asian Social Science Vol. 7, No. 5;pp 170-175.

Owoyemi, T.E. \& Adesoji. F.A. (2012). Isolation of teaching effectiveness factors from Nigerian senior secondary school Chemistry students point of view. British Journal of Arts and Social Science, 9(11), 1.

Patrick, B. (2005). Why children must not be Compared In Education Sight for Quality Information Magazine, Kenya.

Rena, U, 2000. Who will teach : Acase study of teacher education reform? California: Caddo Gap Press.

Rice, J. K. (2003). Teacher Quality: Understanding the Effectiveness of Teacher Attributes. Washington, DC: Economic Policy Institute.

Richardson, A. R. (2008) An Examination of Teacher Qualifications and Student AchievementinMathematicsetd.auburn.edu/etd/bitstream/handle/.../Richardson_Antoine_8.pdf.

Rivers, C. \& Sanders, M. (2002) Statewide Class-size Studies Prime Time and Star, Tennessee's Project Star Dallas Texas.

Rivkin, C and O. Kain, (2003). Relationship between terachers' years of experience and students' achievement. Journal of Research in Education, 2(3): 25-32. 
Role, E.M. (2010).Handbook of Social and Educational Research Methods University of Eastern Africa, Baraton.

Rowan, B. Chaing, F.S., \& Miller, R.J. (1997) "Using research on employees' performance to study the effects of teachers on students' achievement" Sociology of Education, 70(1):256 285.

Ruthland \& Bremer (2002). Teachers' qualification \& experience as predictors of their jod performance. Journal Research in Educational.

Ruthland, S. K. \& Bremer, C. D (2002) 'Alternative Teacher Certification Procedures and Professional Development Opportunities for Career and Technical Education Teachers' Washington D.C.: ERIC Clearinghouse on Teacher Education.

Sikora, D.A (1997). Observable Teachers' effectiveness and personality types of family and consumer services teachers. Unpublished Doctoral Dissertation, The University of Tennessee, Knoville.

Stronge, J.H., Ward, T.J. \& Tucker, P.D. \& Hindman, J.L. (2007)What is the Relationship Between Teachers' Quality and Student Achievement? An Exploratory Study J Pers Eval Educ (2007) 20:165-184 U.N.E.S.C.O. (1986) A

Handbook for Biology Teachers in Africa Paris: United Nations Educational, Scientific and Cultural Organization, 1986.

Wayne, A. J. \& Youngs, P. (2003) Teacher Characteristics and Student Achievement Gains: A Review. Review of Educational Research, 73 (3): 89-122.

Wirth, K.R \& Perkins,D. (2013) Learning to Learn www.malcaster.edu/academics/geology/learning.doc Journal of Education and Practice www.iiste.org.

ISSN 2222-1735 (paper0 ISSWN 2222-2288 (online0 Vol. 4,No 3,2013

Wenglinsky, H. (2000). Teaching the teachers; Different settings, different results. Princeton, N.J: Educational testing service. 